\title{
Trapped in the Land of Liberty: Monika Maron's Animal Triste (1996)
}

\author{
Susanne Rinner
}

orn in Berlin in 1941, Monika Maron moved with her mother to
East Berlin in 1951. Her stepfather Karl Maron was the interior minister of the German Democratic Republic (GDR) from 1955 to 1963. After studying theatre and art history, Maron lived in Berlin as a writer. She was permitted to travel abroad; in addition, she corresponded with the West-German author Joseph von Westphalen. These letters were published in the weekly newspaper Die Zeit between July 1987 and March 1988. Because of this exchange, Maron was not able to publish her first novel in the GDR. Instead, Flugasche was published in the West in 1981. In June 1988, Maron left the GDR and moved to Hamburg. After 1989, Maron engaged with her own and her family's history. In Pawels Briefe, she memorializes her grandfather who perished in the Holocaust. With the opening of the Stasi files, it became known that Maron had worked for the East German secret police in exchange for travel permits to the West, and also that she was subjugated to spying. Her life and her writings are entangled with and chronicle the vexed history of Germany in the $20^{\text {th }}$ century. In 1992, she returned to Berlin where she continues to live and write. Her fiction has been translated into many languages and has received numerous awards, among which are the Kleist-Preis (1992), the Friedrich-Hölderlin-Preis (2003), the Deutscher Nationalpreis (2009) and the Lessing-Preis (2011). ${ }^{1}$

This article focuses on Maron's critically acclaimed novel Animal Triste (1996). Animal Triste tells the story of how the anonymous female first-person narrator, an East German paleontologist, falls in love with a West German hymenopterologist who, in the wake of the fall of the Berlin Wall, inspects the 
Natural History Museum in Berlin where she works. At the time, this love affair was interpreted against the backdrop of the historical event; thus, the novel was understood as an expression of the identity crisis of the narrator in the wake of fundamental historical, political, and social changes. It was also viewed as a symbolic representation of the difficulties of unifying the two German states. ${ }^{2}$ However, most critics have overlooked the novel's contribution to the discourse on the New World, a discourse that has a long-standing tradition in German fiction. In Animal Triste, the narrator's flight to America is precipitated by the fact that the fall of the Berlin Wall, which came to symbolize the end of the Cold War, does not lead to the narrator's liberation. I suggest that the representation of "America" in this novel has outstanding significance, since a trip to Manhattan is the only journey the narrator undertakes at this crucial point in her life. This trip juxtaposes the oppressive GDR state and the chaos of a post-Wall Berlin against the imagined freedom in the New World. ${ }^{3}$ Hence, I argue that Animal Triste offers more than just a reflection on the specific German condition during the Cold War and the confusing aftermath of the fall of the Berlin Wall and German unification. In response to the concrete historical situation, Maron's novel inserts itself into a tradition of writing America as the land of opportunity. The narrator in Animal Triste attempts to escape the immediate political and social demands posed by history and explores the human need for freedom that is placed within the context of a natural history that transcends the history of human civilization. The United States serve as the backdrop against which the tension between freedom, identity, and society can be discussed.

The United States has long enticed the German literary imagination, serving as a screen for projections of utopian promises of life, liberty, and the pursuit of happiness, and of dystopian fears of prevailing exploitation, alienation, and injustice. Since 1989, women writers from diverse backgrounds have participated in the attempt to negotiate the German experience in Manhattan, the island that German writers typically designate as the pars pro toto for the United States. In 2008, Barbara Honigmann published a collection of reflections, written 
during her stay in Greenwich Village, which features a coffee shop called "Space Untitled" as her favorite meeting spot (Das überirdische Licht). West German author Ulrike Kolb uses the same coffee shop in her novel Frühstück mit Max (2000) as a chance meeting space which enables the dialogue between a female narrator, who belongs to the generation of 1968, and her estranged son Max, who lives in Brooklyn. In Milliarden neuer Sterne (1999), East German author Angela Krauß describes her protagonist's trip to New York City as an attempt to fulfill a life-long yearning for the city that was unreachable before the fall of the Berlin Wall. However, once Krauß's protagonist arrives, the city's significance is reduced to a backdrop for her self-exploration as she attempts to experience ultimate freedom.

Maron's Animal Triste constructs the United States as the site to fulfill the protagonist's desire to visit the authentic location of an important paleontological find. The find of remnants of a by now extinct, yet nevertheless related species serves as a symbol for the narrator's yearning for longevity, maybe even eternity. This yearning is juxtaposed with the narrator's life experiences during a time that is marked by rapid change and a never-ending cycle of vanishing and emerging political, social, and public structures. When the protagonist finally reaches the United States, however, she does not leave Manhattan. Instead, the city turns into a literal and symbolic prison that nearly kills her. Manhattan signifies a dystopia, which, like the GDR, does not provide freedom from life's entrapments. ${ }^{4}$

Maron's Animal Triste captures the tension between self-reliance and the desire to form a union with others, by drawing on the symbol of imprisonment. Imprisonment as a philosophical and psychological figure has a long tradition in Western thought. In The Ethics of Memory, Avishai Margalit discusses the notion of life as a prison, asserting that the quintessential prison metaphor is Plato's "Allegory of the Cave." This allegory propounds the idea that there is redemptive knowledge of something that transcends what one can know, a metaphysical knowledge of the ultimately true reality. But there is an inescapable question inherent in this idea. That is, if in the search for this knowledge we never know 
what we are looking for, how can we tell when we have found the thing we are in search of? As Margalit interprets Plato's philosophy, the search for knowledge is an exercise in reminiscence, an effort to recall and recollect that which we once knew or, rather, that which was once knowable.

In connection with Plato's allegory, Margalit points out that in the twentieth century, Freud recreated the metaphor of the prison as the concept of the unconscious. She notes that: "In his prison ward of the unconscious, disturbing memories are locked up by a censor-jailer. They are removed from consciousness, but they are not destroyed; Freud's metaphor is the prison of repression, not the guillotine of forgetfulness."5 Both Plato's philosophical and Freud's psychological metaphors are useful interpretive tools which shed light on the experiences of Animal Triste's narrator as she remembers her romantic involvement. Love is described as a virus that alters a human's state of existence. In the narrator's musings, love either invades the individual like a virus or love, like a prisoner, breaks out from within the individual and subsequently cannot be contained any longer. Additionally, the concept of the prison, which challenges notions of freedom and independence, is juxtaposed with the ideas of human and natural history. The narrator's memories of her experiences in New York City illustrate the complex entanglement of these ideas. These memories highlight the narrator's ultimately failed attempt to flee her self-inflicted imprisonment and to liberate herself in the New World in order to live a self-determined life with her lover Franz.

The narrative situation in Animal Triste resembles the genre characteristics of a fictitious autobiography. The narrator bases her life story on her own memories. In fact, the narrator asserts that she stopped living her life in order to be able to continuously relive and, in doing so, to reconstruct her memories of her love affair and hence, to take control of the narrative and, at least in retrospect, of the events themselves. The narrator claims to have forgotten her real age, musing that she could be nearing 100 years of age. ${ }^{6}$ She is convinced that she is faced with imminent death and hence, decides to relive her love affair one more time, 
possibly the last time. ${ }^{7}$ Her storytelling takes on an urgency that captivates the reader even though the reader already knows that the love affair has failed, ended presumably years ago, leaving the narrator lonely and longing.

Since the narrative consists of the narrator's memories, it defies the stringent straitjacket of chronology. The only specific historical reference in the text is the fall of the Berlin Wall. This event, monumental in its historical significance, has a profound impact on the narrator's life. Shortly after the opening of the Berlin Wall, the narrator experiences a fainting spell whose exact medical cause remains unknown. The narrator feels its effects for several weeks and interprets the event as a simulation of her own death and, thus, as a reminder of her own mortality. As a scientist she begins to question her prior assumptions about life and death, scientific theories and religious beliefs. "For the first time in my life, I wondered why the theory of evolution is thought to disprove the existence of a higher reason; evolution might just as well be the creation of that reason." ${ }^{8}$ She decides that the only thing that one can miss out on in life is love. 9 Hence, the fall of the Berlin Wall and her fainting spell entice her to leave her previous life behind. It remains unclear whether she leaves her husband, or her husband leaves her or has passed away. Her daughter remains a faint memory. These references to the narrator's life do not help establish a chronology or a linear storyline, yet they reinforce the importance of the fall of the Berlin Wall. The Wall that used to divide space into East and West now divides time into before and after. The time period immediately after the opening of the Berlin Wall enables everybody - or at least creates the illusion that everybody is able- to escape the confinements of their previous lives behind the Wall. "Everybody saw a secretly awaited sign in the unexpected change of the time. Some may give themselves over to ultimate resignation, and others accept this second chance for life even at the risk of total failure." 10 The narrator's response to the situation, having recognized that love is the only thing that one can miss out on, is to meet Franz. While the narrator claims to clearly remember him, she does not recall his 
name, calling him Franz since she does not remember knowing anyone else with that name. ${ }^{11}$

The narrative situation imprisons the narrator as much as it serves as liberation. While the narrator is free to reconstruct her own memories, her reconstructions ultimately fail to provide a coherent ending for her story. Repeatedly, the narrator emphasizes that her memories are faulty and incomplete. In addition, these memories and the memory process trap the narrator literally and figuratively. The narrator refuses to leave her apartment. She avoids all social contact with others so that she will not be disturbed in the process of remembering her love affair with Franz. Her apartment encloses her like a prison and serves as a memorial of her love affair, facilitating processes of remembering and forgetting without liberating her. Even though the affair ended long ago, the narrator still longs for Franz. This longing shapes the compulsive repetition of memories of the affair which entrap her, as she focuses on telling only those memories that support her construction of her life story. The narrator comments on the slow process of aging that facilitates her escape from the trappings of reality and history and allow her to forget and to reconstruct memories at her own pleasure. In fact, she facilitates this process by wearing the glasses that Franz forgot to take with him. By wearing glasses that she does not need, she distorts and ultimately ruins her vision which enhances her ability to view her own life with different eyes, namely with blurred vision. She emphasizes the liberating effects of forgetting memory traces that threaten her understanding of the love affair. Hence, she serves as an unreliable narrator who calls into question the narrative she outlines. This play between historical reality and (re)invention of the past creates a double bind for the reader. The narrator's memories function as a prison that do not allow access to the historical truth of her life, since she admits that these memories are merely reconstructions of the past, flawed as all memories, incomplete, overwritten, constructed, or repressed.

Animal Triste suggests that every form of freedom, when looked at from a different perspective, represents a kind of confinement as well. As the narrator 
remembers her love affair, her infatuation with Franz, whom she meets during the time of upheaval and change that lifted the restrictions imposed by the GDR and seemed to open new opportunities and greater freedoms, signifies another kind of entrapment. The narrator remembers their first encounter in the Natural History Museum. One day, the narrator enjoys a peaceful and contemplative moment at her favorite place underneath the skeleton of the brachiosaurus, her beloved dinosaur fossil. Then, suddenly, Franz surprises her with his remark, "a splendid beast." $" 12$ This comment triggers in the narrator a recognition that Franz is her soul mate and true love. Since Franz is married, a passionate, albeit illicit affair ensues, which leaves the narrator increasingly unhappy and trapped, and she pressures Franz to decide between her and his wife. The decision seems to have been made when Franz goes on a vacation with his wife to visit Hadrian's Wall in Scotland. During his absence, the narrator stays at home alone, thinking obsessively about him, particularly about his sexual encounters with his wife. The narrator is trapped even though the fall of the Berlin Wall seemed to allow for liberation.

The ubiquitous construction sites in post-unification Berlin configure obstacle courses that reflect the narrator's inner despair during Franz's absence and in light of his continued commitment to his wife. They trigger her decision to travel to the United States, since they prevent her from reaching the museum that represents soothing continuity among the dinosaur fossils and replica that symbolize a natural history that outlives human history, since they are literally set in stone. Thus the narrator decides to make use of the opportunity created by the surprising end of the GDR and by her lover's absence to travel to the United States, to South Hadley in Massachusetts. She calls the site "Pliny Moody's Garden" since Pliny Moody, a farmer's son, discovered the first confirmed evidence of a dinosaur to be found in North America in $1802 .^{13}$ This trip evokes the topos of the United States as a country without memory, and thus without the burden of a past, mirroring the narrator's decision to willfully forget her own history, with the exception of Franz. The notion of America as a land of opportunity that is forward- looking rather than being held back by the past has a 
long tradition in German fiction. Already Johann Wolfgang von Goethe juxtaposed the New World with the Old World in this vein in his poem "America." ${ }^{\prime 14}$ He emphasized that the opportunity to look forward would prevent immigrants from being held back by strife that erupts in countries with long histories. The narrator of Animal Triste escapes the prison created by her compulsive longing for Franz by fulfilling her dream to visit the site of important discoveries of dinosaur fossils. ${ }^{15}$ Since the narrator's wish to travel to South Hadley in order to visit Pliny Moody's garden predates her affair with Franz, it also functions as a reminder of the lack of freedom in the GDR; in particular, it highlights the lack of freedom to travel, since the narrator was not allowed to journey to the United States before the fall of the Berlin Wall. Thus, the trip to the United States not only evokes the possibility of "true" forgetting, as opposed to merely repressing memories, but also of complete personal freedom. That the narrator purposefully chooses South Hadley over other destinations is further emphasized by her comment that her former husband and she could never agree on where to travel. She wanted to go to South Hadley in order to see evidence of evolutionary history and he preferred to travel to Greece to see the cradle of Western civilization.

South Hadley functions as an "Erinnerungsraum"16 that provides the opportunity for contact with a past that predates civilization and is structured according to geological and evolutionary time scales. The narrator's professional expertise as a paleontologist places her autobiographical experiences into an archaic chronology that transcends human civilization. Since the origin of life dates back to some 3.5-3.6 billion years ago, paleontologists have a different scale of time than historians of (human) civilization. Because of this, processes of remembering and forgetting intersect with the narrator's preoccupation with dinosaurs and the history of evolution. This intersection is crucial for her understanding of emotions and anthropological concepts, in particular of freedom and identity. In anticipation of her visit, the narrator attributes metaphysical, indeed religious significance to the site by describing it as a natural paradise. 
"Pliny Moody's garden was an uncultivated paradisiac plot of land, mysteriously quiet, bright, and yet shady, where a soft wind cooled the heat. ${ }^{" 17}$ Her description of South Hadley adds a new dimension to the narrator's memories that had been lacking so far, namely the acknowledgement that life and its manifestations can be understood beyond the purely material and tangible.

The decision to visit this site of great paleontological interest and to turn it into a space of personal, historical, and metaphysical importance enables the narrator to contextualize her relationship with Franz and to provide an alternative understanding of her own life and of recent German history. Neither the fall of the Berlin Wall nor her relationship with Franz satisfy the narrator's desire to experience freedom and to realize her full potential as a human being. "For me all this wasn't enough. I longed for something cataclysmic, something into which all the postage stamps, street names, and uniforms would flow, the extended motion into a different dimension, perhaps a dramatic change of climate, a flood or other natural disaster, at any rate something that was larger than human beings and their ever-changing desires. Of course, nothing happened. ${ }^{18}$ Hence, the narrator plans a trip to South Hadley where she expects to be able to connect with the traces of a natural history that transcend human civilization and add metaphysical significance to her life and her self-understanding. She evokes the history of prehistoric dinosaurs and their traces, found, ironically, in the so-called New World, in order to juxtapose this history with a more conventional understanding of time.

In her use of South Hadley as a location in the New World and of significant evolutionary processes, I argue that the narrator does not solely engage her relationship with Franz and her experiences in the former GDR, but also examines existential questions that potentially undermine conventional anthropological determinations of humans as free and self-determined. The narrator suggests that changes triggered by natural causes, such as natural disasters, far outweigh the opportunity for radical change in any attempt by humans to alter history. She reaffirms her belief in nature and its superiority over 
civilization: "All my life I believed too intensely in nature to be a good human being. ${ }^{19}$ During this narrative memory process, she affirms that historical time, as measured by political and social developments, does not necessarily contribute to a better understanding of human nature, and that events like the fall of the Berlin Wall that are considered to be radical changes, or even revolutions, do not serve as a liberation for individuals. Notions of progress, and claims about the eternal duration of political systems, social contracts, and religious sacraments, such as marriage, prove to be only short-lived, especially if juxtaposed with a history of nature, in which the notion of love is understood as an affect that comes into existence according to the laws of evolution.

Upon her arrival in the United States, the narrator never leaves New York City. At first, she enjoys the urban jungle of Manhattan, which helps fulfill her wish to experience personal freedom and to recover her identity. She rationalizes retrospectively that South Hadley had lost its attraction after the fall of the Berlin Wall, since the United States in general and South Hadley in particular had become attainable destinations, frequented by mass tourism, which, in turn, made them lose their utopian promise and appeal. The large apartment her friends have allowed her to use is described as part jungle, filled with tall plants, and as part emptiness. Numerous windows allow the noise of the city to enter the apartment, creating the illusion that boundaries are dissolved between the inside and the outside, which thus produces a sense of unity within the narrator. The narrator explores the city on foot, then recovers in the apartment, where she feels "strangely yet securely nestled." She surrenders to the heroic feeling of her solitude and believes, for the first time since her affair with Franz, that she could actually be happy without him. ${ }^{20}$ This feeling of happiness is triggered by the narrator's contemplation that the city with its "skyscrapers, air-conditioning systems, ice machines, and the ceaselessly screeching ambulance sirens" provides her with a "sense of freedom like an animal in its natural habitat." She points to the paradoxical experience that the city as the manifestation of modernity enables 
people to regain their original nature. ${ }^{21}$ Hence, her desire to visit South Hadley in order to connect with a natural history that transcends civilization decreases.

Yet, her euphoria about having found access to a utopia that promises happiness and freedom is short-lived. The island of Manhattan ultimately functions like yet another prison. First, the narrator locks herself in, turning her loft into a prison. As she contemplates her situation, she develops paranoia comparable to the feeling she experiences whenever Franz leaves her in the middle of the night in order to return to his own apartment and his wife. Finally, however, she realizes that her imprisonment is self-induced, since she had failed to unlock the safety bolt at the door. Secondly, the narrator attempts to visit a friend; however, she fails to obtain directions to her friend's apartment from the doorman. As she attempts to find the apartment by herself, she wanders through increasingly smaller rooms that seem to be stacked within each other like a matryoshka doll. Even though she follows the exit signs, they turn out to be misleading, and in the end she is trapped in a broom closet. Since she cannot free herself, she begins to panic, knocking on the door and hysterically calling for help. Finally, someone simply opens the door from the other side, and the narrator flees the building without meeting her friend. These two experiences emphasize the fact that feelings of entrapment are often just that-feelings that do not indicate a physical entrapment. At the same time, even though the narrator attempts to liberate herself, these two events indicate that mental and psychological barriers are harder to overcome than physical ones. In addition, the notion of self-sufficiency is challenged since the narrator could have avoided some of these situations had she communicated with others.

The third incident does not entrap the narrator, but threatens her life, and hence triggers her abrupt return to Berlin without visiting South Hadley. The narrator accepts an invitation to attend a party in order to meet a friend's friend. However, as she arrives at the building, she does not enter immediately, but instead waits for her friend in front of the house. She contemplates the quiet neighborhood and feels triumphant about her arrival in the New World. She feels 
as if her journey to the United States, even though she has not traveled on to South Hadley and she continues to experience entrapments, nevertheless allows her to realize herself. As she experiences this positive rush of emotions a sudden intuition hits her: "This is not a good place to stand." 22 In response, the narrator crosses the street and just as she reaches the opposite sidewalk, a car, chased by the police, loses control, flips over, and hits the fence at the spot where she was standing just seconds before. With ironic detachment, she is excited to have observed a scene that is familiar from American gangster movies. However, this incident also constitutes a traumatic experience since she comes to realize that she would probably have been hit by the car and would have died if her inner voice had not warned her of the danger. Devastated, she draws a connection between this incident and her earlier fainting spell in Berlin, another near-death experience. Whereas in Berlin she used her momentary loss of consciousness as an opportunity, in New York, she visualizes how this accident could have turned her into an anonymous corpse, remembered by no one. Thus New York City, rather than granting her freedom, seems to capture and confine her and ultimately threatens her life.

As a paleontologist, the narrator understands the implications of being a corpse. A skeleton entails information about the past and reveals insights into past worlds. The narrator highlights the connection between the history of civilizations and the history of nature, histories that meet in the specific location where fossils that document extinct species are found. Paleontological work thus mirrors the narrative process of remembering. Just as skeletons can be excavated, reassembled, completed, reproduced, and analyzed, narrating memories entails attempts to access the past as well as to recreate and reconstruct this past. In her recollections, the narrator slowly radicalizes her understanding of paleontology as a work of recovery and remembering, by appropriating a history of nature that allows her to focus solely on existential needs, in particular her need to spend time with Franz, in the face of and against all moral and ethical demands. "I realized only much later that my indomitable feelings for Franz consisted in their 
saurian nature, or differently: I understood that it was the saurian nature in me that made me love the way I did, something primeval, atavistically violent, something disdainful of all civilizing norms, and nothing requiring language could prevail against my love for Franz." ${ }^{23}$ The narrator describes herself as a dinosaur and recognizes that her love affair violates societal rules. Her attempt to describe her love as feelings that exist beyond language and hence beyond the boundaries of civilization and to interpret them as expressions of nature that escape any moral and ethical considerations can be seen as an attempt to justify her continued effort to maintain the relationship with Franz even against his wishes.

Through the incidents of entrapment and near-death in New York City, the narrative suggests that it is impossible to live outside civilization; it also shows that any experience of love and freedom is juxtaposed with the limitations of civilization and life itself. Combining these insights, which she has gained on the threshold between life and death, the narrator decides to return to Berlin in order to make herself available to Franz and to mend their broken relationship. Their first meeting after the separation seems to confirm that only romantic longing and its fulfillment offer an escape from the civilized world and are able to superimpose nature and civilization. "Beautiful as a pale-skinned beast Franz lies stretched out between the carnivorous plants. When I caress his skin, I feel as if I am caressing myself. Sometimes I can't tell the difference between me and Franz." 24 Both lovers are inseparable, in tune with nature, and both are described as animals. "I dug my stubby animal nose into the hollow space between Franz's shoulder and neck." 25 Love is cast as nature and as determined by nature, a utopian, authentic, and life-enabling moment that overcomes human alienation. Frequent references to literary lovers throughout Animal Triste, including Orpheus, Tristan and Isolde, Romeo and Juliet, Anna Karenina, Werther, and Penthesilea, add a reflective layer to the lived experiences and point to the tight connection between love and death, and love and freedom. As such, the representation of love not only points to its emotion, (physical) longing, and desire as the foundation of life, but also to its potentially life-threatening passion 
and destruction. These two facets foreshadow the end of the story, with the ultimate failure of the narrator's utopian expectations regarding Franz and Pliny Moody's garden. Dinosaurs faced extinction, the Berlin Wall fell, and human life is characterized by its finite nature, and its unpredictable end in death.

Animal Triste is a narrative constructed of memories, which lose precision and coherence and, in the end, lead to a surprising revelation that contradicts the narrator's attempt to find herself through love. At the beginning, she claims to have detailed and accurate memories of her lover, with the exception of his name and his reason for leaving her. Toward the end of the story, the narrator uses numerous strategies in order to slow down the narrative. She muses on how the process of remembering becomes increasingly difficult and how her ability to differentiate between the possible and the true events decreases. These narrative strategies not only captivate the reader's attention, but they also fulfill an important psychological function as repressions of uncomfortable memories. Yet, no matter how hard the narrator tries, in the end, she cannot repress the painful truth that Franz indeed left her and, equally important, that she bears responsibility for his disappearance. The narrator recalls an apparently deadly accident which explains Franz's sudden disappearance. At the same time, she vaguely remembers that she pushed Franz in front of a bus. This tension between accident and foul play remains unresolved and characterizes the narrator as unreliable and her memories as carefully constructed and, at the same time, repressed. Franz's death mirrors the auto accident that the narrator narrowly escaped in New York City, and as such had a profound impact on her. Killing Franz, whether the reader chooses to understand this scene literally or figuratively, points to the narrator's agency in the story. She is not only exposed to the events, but, as the narrator, she creates them. Hence, for her, freedom lies in the act of narrating the story as she remembers it. Her choice of plot ending, however, prohibits her from maintaining her love affair with Franz and hence, leads to further isolation. Since the narrative revolves in circles around the narrator, she is trapped in a maze of her own obsessive memory. 
The narrator's loss of Franz triggers her prison-like seclusion in her apartment in Berlin. This seclusion is painfully documented by the consciously selected memories that constitute her version of the story. At the same time, only this seclusion allows her to shape this story. With the departure of her lover, she is left without any expectations, dreams, or hopes. Her complete despair is symbolized in her loss of interest in and her disillusionment with her professional passion: "Just as the birdlike footprints in Pliny Moody's garden disappeared in New York into the realm beyond promises, so did the brachiosaurus change into what he really was: a skeleton, whose bones were mostly not the real thing anyway, but ingenious imitations. ${ }^{26}$ Her professional disillusionment can serve as a comment on her story telling. Her construction of a fictitious autobiography does not provide access to any kind of truth, be it historical, scientific, or even personal. Yet, her story provides an important exploration of the never-ending quest for freedom and personal fulfillment.

In Animal Triste, the representation of the United States as utopia entails the notion of a destination that cannot be reached, since the reality of a place threatens to destroy its imagined promise. Maron's novel provides a critical commentary on the utopia of life, liberty, and the pursuit of happiness as they are represented in the symbolic image of America in German fiction. Her text also engages the tradition of the dystopian dimension of the New World. Manhattan cannot fulfill the narrator's quest for liberty. Contemplating her life while facing the brachiosaurus, the narrator observes that one cannot blame a prisoner who was longing for freedom while she was behind walls, if she suddenly realizes, once the walls become obsolete, that these same walls were actually the preconditions for her happiness. ${ }^{27}$ 


\section{Bibliography}

Assmann, Aleida. Erinnerungsräume. Formen und Wandlungen des kulturellen Gedächtnisses. München: Beck, 1999.

Byrnes, Deirdre. "Love and Loss after the Wall: Animal Triste." Rereading Monika Maron. Text, Counter-Text and Context. Oxford: Peter Lang, 2011: 97-116.

Fastovsky, David E. and David B. Weishampel. The Evolution and Extinction of the Dinosaurs. Cambridge: Cambridge University Press, 2005 (2nd edition).

Geier, Andrea. "Paradoxien des Erinnerns: Biografisches Erzählen in Animal Triste." In: Gilson, Elke, ed. Monika Maron in Perspective: 'Dialogische' Einblicke in zeitgeschichtliche, intertextuelle und rezeptionsbezogene Aspekte ihres Werkes. Amsterdam: Rodopi; 2002: 92-122.

Harbers, Henk. "Gefährliche Freiheit. Zu einem Motivkomplex im Werk von Monika Maron." In: Gilson, Elke, ed. Monika Maron in Perspective: 'Dialogische' Einblicke in zeitgeschichtliche, intertextuelle und rezeptionsbezogene Aspekte ihres Werkes. Amsterdam: Rodopi; 2002: 123-138.

Lewis, Alison. "Re-Membering the Barbarian: Memory and Repression in Monika Maron's Animal Triste.” German Quarterly 71.1 (1998): 30-46.

Margalit, Avishai. The Ethics of Memory. Cambridge, London: Harvard University Press, 2002.

Maron, Monika. Animal Triste. Translated by Brigitte Goldstein. University of Nebraska Press: Lincoln and London, 2000 (German edition: Frankfurt a.M.: Fischer, 1996.)

\footnotetext{
${ }^{1}$ For detailed information on publications and secondary literature please refer to Kritisches Lexikon zur deutschsprachigen Gegenwartsliteratur, ed. Heinz Ludwig Arnold, 1-12 (Munich: Edition Text und Kritik, 1978ff.) which contains an entry on Monika Maron by Eckhard Franke and Roman Luckscheiter from January 2005.

${ }^{2}$ See e.g. Deirdre Byrnes. "Love and Loss after the Wall: Animal Triste." Rereading Monika Maron. Text, CounterText and Context. Oxford: Peter Lang, 2011: 97-116. Andrea Geier. "Paradoxien des Erinnerns: Biografisches Erzählen in Animal Triste." In: Gilson, Elke, ed. Monika Maron in Perspective: 'Dialogische' Einblicke in
} 
zeitgeschichtliche, intertextuelle und rezeptionsbezogene Aspekte ihres Werkes. Amsterdam: Rodopi; 2002: 92-122; and Alison Lewis. "Re-Membering the Barbarian: Memory and Repression in Monika Maron's Animal Triste." German Quarterly 71.1 (1998): 30-46.

${ }^{3}$ In another context, the narrator refers to the utopia of America with irony: "like the longingly expressed commonplace - our children should be better off one day - that motivated parents to move from mountains into valleys, from villages into towns, and from everywhere to America." (Animal Triste, 48.)

${ }^{4}$ Henk Harbers describes a similar dystopian turn with respect to the utopian potential of the imagined south in Maron's story “Das Mißverständnis” (1982).

${ }^{5}$ Margalit, 2.

${ }^{6}$ Animal Triste, 11.

${ }^{7}$ Animal Triste, 18.

${ }^{8}$ Animal Triste, 8.

${ }^{9}$ Animal Triste, 9.

${ }^{10}$ Animal Triste, 52.

${ }^{11}$ Animal Triste, 2 and 6.

${ }^{12}$ Animal Triste, 9.

${ }^{13}$ Animal Triste, 44.

14 “America, you're better off than / Our continent, the old. / You have no castles which are fallen / No basalt to behold. / You're not disturbed within your inmost being / Right up till today's life / By useless remembering / And unrewarding strife.” J.W. Goethe, “To America," trans. Stephen Spender. The Permanent Goethe, ed. Thomas Mann. New York: Dial, 1948: 655. Original: "Den Vereinigten Staaten.” in: J.W. Goethe. Werke. Volume 1. Ed. Erich Trunz. Beck: München, 1981.

${ }^{15}$ The compulsion to remember that drives the narrative is thus mirrored in the compulsion to remember Franz during his brief absence from Berlin. This mirroring illustrates the philosophical metaphor of Plato's cave where we only see the shadows of the things that themselves represent the ideas which are ultimately not accessible to us humans.

${ }^{16}$ I am borrowing this term from Aleida Assmann's title, Erinnerungsräume. Formen und Wandlungen des kulturellen Gedächtnisses, in order to indicate the entanglement of space and time in processes of remembering and forgetting.

${ }^{17}$ Animal Triste, 44f. In 1802, a boy named Pliny Moody noticed dinosaur tracks on his father's farm in South Hadley, Massachusetts. In 1836, more tracks were found at a quarry near Montague, Massachusetts. They were described by the Reverend Edward Hitchcock, president of Amherst College in the American Journal of Science. He described 11 different kinds of track ways by a giant three-toed bird that he termed Ornithichnites. With this publication, Hitchcock is recognized as the first scientist to record North American dinosaur trace fossils. -- The 
name Pliny also evokes the Roman Pliny the Elder, author of the encyclopedic work Natural History, opening another frame of reference to history and scientific discovery.

${ }^{18}$ Animal Triste, $46 \mathrm{f}$.

${ }^{19}$ Animal Triste, 90.

${ }^{20}$ Animal Triste, 121.

${ }^{21}$ Animal Triste, $121 \mathrm{f}$.

${ }^{22}$ Animal Triste, 126.

${ }^{23}$ Animal Triste, 71.

${ }^{24}$ Animal Triste, 101

${ }^{25}$ Animal Triste, 115 and "[...] and the evening when I held Franz in a monkey embrace [...]." (Animal Triste, 118)

${ }^{26}$ Animal Triste, 130.

${ }^{27}$ Animal Triste, $71 \mathrm{f}$. 